Chapman University

Chapman University Digital Commons

Sociology Faculty Articles and Research

Sociology

2009

\title{
In God We Trust: Images of God and Trust in the United States among the Highly Religious
}

F. Carson Mencken

Baylor University

Christoper Bader

Chapman University, bader@chapman.edu

Elizabeth Embry

Baylor University

Follow this and additional works at: http://digitalcommons.chapman.edu/sociology_articles

Part of the American Studies Commons, and the Religious Thought, Theology and Philosophy of Religion Commons

\section{Recommended Citation}

Mencken, F. Carson, Christopher D. Bader and Elizabeth Embry. 2009. "In God We Trust: Images of God and Trust in the United States among the Highly Religious." Sociological Perspectives 52: 23-38.

This Article is brought to you for free and open access by the Sociology at Chapman University Digital Commons. It has been accepted for inclusion in Sociology Faculty Articles and Research by an authorized administrator of Chapman University Digital Commons. For more information, please contact laughtin@chapman.edu. 


\section{In God We Trust: Images of God and Trust in the United States among the Highly Religious}

\section{Comments}

This article was originally published in Sociological Perspectives, volume 52, in 2009.

\section{Copyright}

University of California Press 


\title{
IN GOD WE TRUST: IMAGES OF GOD AND TRUST IN THE UNITED STATES AMONG THE HIGHLY RELIGIOUS
}

\author{
F. CARSON MENCKEN \\ CHRISTOPHER BADER \\ ELIZABETH EMBRY \\ Baylor University
}

\begin{abstract}
In this analysis, the authors use Greeley's "religion as poetry" model to frame an analysis of images of God and trust among the highly religious. Using the 2005 Baylor Religion Survey, the authors regress four ordinal measures of social trust on two images of God measures and a bank of religion and demographic controls. The authors find that having a loving image of God creates greater levels of trust in all four measures among the highly religious. They also find that having an image of God as angry creates less trust in all four measures of trust. Implications for theory and research on trust and civic engagement are discussed in the conclusion.

Keywords: trust; religion; image of God
\end{abstract}

Sociologists and other social scientists have spent considerable intellectual energy investigating the causes and consequences of trust (cf., Brehm and Rahn 1997; Clairbourn and Martin 2000; Fukuyama 1995; Veenstra 2002; Yamagishi, Cook, and Watabe 1998). Trust is one of the core sociological concerns for understanding social cohesion, interpersonal relations, and the interconnection between microlevel interaction and macrolevel structures (Coleman 1988, 1990). It is argued by many to be the cornerstone for the formation of social capital and social cohesion in any group, from the smallest dyads and triads to complex, postindustrial societies (see Macy and Skvoretz 1998; Paxton 2000; Putnam 2000; Saguaro Seminar 2000).

In this article, we seek to add to the broader understanding of trust formation in America by examining the formation of trust among highly religious Americans (who compose a significant proportion of the population). Data from the World Values Survey show that Americans hold more traditional values and are more religious than other postindustrial nations, with the exception of Ireland (Norris and

Address correspondence to: Dr. F. Carson Mencken, P.O. Box 97326, Waco, TX 76798-7326; e-mail: Carson_Mencken@ baylor.edu.

Sociological Perspectives, Vol. 52, Issue 1, pp. 23-38, ISSN 0731-1214, electronic ISSN 1533-8673.

(c) 2009 by Pacific Sociological Association. All rights reserved. Please direct all requests for permission to photocopy or reproduce article content through the University of California Press's Rights and Permissions website, at http://www.ucpressjournals.com/reprintinfo.asp. DOI: 10.1525/sop.2009.52.1.23. 
Inglehart 2004). According to the 2004 General Social Survey, 58 percent of Americans pray at least daily, and 41.6 percent attend church at least twice a month (see Bader, Mencken, and Froese 2007:458). More specifically, we seek to build on past models that emphasize denominational and church attendance differences (Uslaner 2001; Welch et al. 2004) and focus on a more basic building block of trust: an individual's religious narrative and its central symbol, the image of God.

One important theme that has emerged from the research on religion and trust is the bifurcation of trust into generalized and particularized trust (Stark and Finke 2000; Uslaner 2001, 2002; Welch et al. 2004; Welch et al. 2005; Wuthnow 1998). Religion can serve both a bridging and a bonding function. Religious values encourage people to do good things and to volunteer in their communities (Uslaner 2001). Churches help bridge the gap between social groups, exposing church members to a wider diversity of people. Participation in a religious community can create a sense that people are decent, good, and trustworthy (Wuthnow 1998:195; see also Uslaner 2002; Welch et al. 2005; Wuthnow 1991). As Uslaner (2001) points out, many denominations have taken active roles in promoting social justice and civic activism. Moreover, participation in religious life creates a bond among members of the congregation. This, in turn, creates familiarity, predictability, and trust.

While there are reasons we can expect religion to increase trust, there are equally good reasons to believe that participation in religious communities may diminish generalized trust. Members of religious congregations may form "particularized trust" through social bonding with others who share a "skeptical" world view. According to Wuthnow (1998), when trust is based on a "common framework" of values held by a group, members may trust one another but have little reason to trust outsiders. The more social ties created in a religious organization, the more conformity there will be to the ideals of the organization. Yet this may also restrict the external social ties of the group, leading to fewer opportunities for contact with nonmembers. Uslaner (2001:104) summarizes this idea well:

Generalized trusters feel a moral imperative to help strangers, since we are all part of the same moral community. Particularized trusters only place faith in their own kind. They view strangers with suspicion, fearing that others may not share their values and may even threaten the things that they hold dear.

\section{Images of God: Religion as Story}

The literature on religion and trust indicates a bifurcation of trust into particularized and general trust. We argue that Greeley's theory of "religion as poetry," with the image of God as its central religious symbol, is essential to understanding why some religious groups in the United States form particularized trust while others form general trust.

Working from the assumption that humans create a world of symbols through which life is interpreted and "truth" is established, religious people interpret events based on a preexisting set of religious symbols that are retained in memory (Greeley 1995; Smith 2003). Religion is a set of such symbols that give ultimate meaning to life and provide templates used to construct reality and interpret experiences. ${ }^{1}$ According to Greeley (1995:124), the central religious symbol is God; 
one's "picture of God is in fact a metaphorical narrative of God's relationship with the world and the self as part of the world." Furthermore, organized religious communities are storytelling communities. It is through these communities that we learn God's "story."

Christian Smith (2003) proposes that humans are moral, believing animals that place their faith in nonhypothetical truths. At a subconscious level, humans carry with them a narrative that explains how and why the world works the way it does (see also Somers 1992). The religious narrative is one of the most powerful forces, for it "tells people not only what is real but also consequently what are good, right, true, wise, and worthy desires, thoughts, feelings, values, practices, actions, and interaction" (Smith 2003:99). Narratives provide a systematic organization of orientations and actions, beliefs and practices. As Smith points out, because religion answers to "the reality of superempirical orders," it is a powerful narrative in some lives as it provides the answers to the ultimate questions of meaning.

We propose that different religious story communities have different degrees of moral absolutism (see Baker 2005; Froese and Bader 2007). At a basic level, moral absolutism is bifurcated based on analogical versus dialectical religious imaginations. For example, Greeley (1995) argues that Catholics are more analogical—God is Creator and discloses himself in the world. Moreover, those who see God as creator see only goodness and are likely to support the image of a loving God and be more forgiving and less absolute in their moral judgments.

In contrast, those who have a dialectical imagination see God as having forsaken humanity. God and the world are separate. Humans are flawed and failed. God is angry and will judge humanity for its sins. Those with greater moral absolutism in their religious imaginations are more likely to see God as angry and judgmental (Froese and Bader 2007; Stark 2001a, 2001b). If an image of God is a central part of one's religious story, as Greeley argues, it follows that conceptions of the divine organize their world and affect how a person interacts with others. People who see God in more compassionate and forgiving terms will tend to treat others with compassion and forgiveness. However, people who have a symbol of God as angry and judgmental will tend to be more individualistic and less tolerant of others (the forsaken).

It would be oversimplifying the argument to state that all Catholics have an image of God as loving and caring and all Protestants see God as judgmental and wrathful. The key, then, is moral absolutism in the religious narrative. Research shows that storytelling communities - congregations, denominations, traditionshave greater or lesser degrees of moral absolutism (cf., Steensland et al. 2000). Regardless of the denomination or tradition, those whose religious story is grounded in communities with greater moral absolutism will have religious narratives and images of God that are consistent with greater degrees of moral absolutism.

Studies suggest that how one views God affects how one views others. Froese and Bader (2007) argue that actors attribute a "personality" to God that reflects self-identified desirable human traits. Indeed, Greeley (1988, 1989, 1991, 1993, 1995) finds images of God to be associated with a variety of different moral, social, and political attitudes. These findings are consistent with other research. For example, Unnever, Cullen, and Applegate (2005; see also Unnever, Cullen, and 
Bartkowski 2006) find a negative relationship between support for the death penalty and an image of God as compassionate and gracious. Froese, Bader, and Smith (2008) show that an authoritative image of God is negatively related to political tolerance and positively related to tools of violence (gun ownership, death penalty, and defense spending). Ellison (1991) concludes that violence and an authoritative image of God are positively correlated among Southerners. ${ }^{2}$

Yet none of these studies explicitly analyzes the link between image of God and trust. Ozorak (2003) examines the relationship between images of God and volunteering outside of the church. Among those who already volunteer, those who did so because of intrinsic motives ("called to see Christ in the face of those in need") were more likely to repeat their volunteerism than those who volunteered initially because of extrinsic motives ("Christians must help those in need in order to earn salvation or avoid eternal damnation"). This seems to indicate that those who helped others because they felt that God was loving and supportive were more inspired by their images than those who felt that God was vengeful and angry. This finding is consistent with the thesis that those who see God as loving are likely to be more trusting.

Welch et al. (2004) make a connection between social trust and denominational beliefs: Mainline Protestants, because they believe in human sinfulness, but also common grace, human potential, and human goodness, should have higher levels of social trust than their more conservative Protestant counterparts. Conservative Protestants, on the other hand, who hold stronger beliefs about human sinfulness, may be less trusting of people in general, because they hold a vengeful God view, with only a few being chosen for salvation. The few are those who share the same beliefs as they do, which leads them to trust others in their congregations but not people in general.

Following Greeley, we believe that images of God should significantly affect trust of others. Those who carry a religious symbol of God in their memory as very judgmental of humanity may be less likely to trust those they deem "unworthy." Those who tend toward more benevolent views of God should transfer that benevolence to others-being more likely to trust those outside their inner circle. In this article, we examine if, in fact, images of God have such an effect when controlling for other key religion measures.

\section{DATA AND METHODS}

The data used in this study are from the 2005 administration of the Baylor Religion Survey (BRS). Consisting of a random, national sample of 1,721 U.S. citizens, the BRS was administered and collected by the Gallup Organization. ${ }^{3}$ We limit the analysis to the highly religious: those who have no doubt about the existence of God. If you doubt the existence of God, then the centrality of the God symbol in your religious narrative should be less influential. In the case of the United States, this should not pose conceptual problems. Compared to most postindustrial nations, the United States is a very religious nation (Norris and Inglehart 2004). Moreover, 66 percent of BRS respondents report no doubt about the existence of God. ${ }^{4}$ Those who have no religion are not likely to have a religious imagination 
and hence no image of God. Because they are such a small portion of the total sample, we eliminate those of "other" religions from the analysis. Our final sample includes Christians and Jews who have no doubt about the existence of God.

This subsample has the following demographic characteristics: 85 percent are white, 58 percent are female, and the mean age is 48.4. Twenty-four percent are Catholic, 6.8 percent black Protestants, 43.1 percent Evangelical Protestants, 23.2 percent Mainline Protestants, and 1 percent Jewish. Forty-three percent attend church at least once a week. Thirty-two percent are from the South and Midwest, respectively. Forty-two percent have at least a four-year college degree, and 16.7 percent have annual household incomes exceeding $\$ 100,000$. Compared to the full BRS sample, the highly religious are more likely to be female, slightly older, and from the South and Midwest. They are also slightly better educated. However, given how well the 2005 BRS compares to the 2004 General Social Survey on core religiosity measures (see Bader et al. 2007), we do not believe that our subsample of the highly religious is misrepresentative of the highly religious population in the United States.

\section{Dependent Variables}

Trust Measures. Using the possible responses "not at all," "only a little," "some," and "a lot," respondents were asked "How much would you say you trust the following people or groups?" We have four Likert-type measures of trust in the analysis: (1) people in general, (2) neighbors, (3) coworkers, and (4) people who do not believe in God. The first three measures are similar to those used by others to measure general trust (see Welch et al. 2004). The last measure is used to examine the relationship between images of God and those who do not believe in God and may be viewed as extreme outsiders by the highly religious.

\section{Independent Variables}

Religion Measures. Because past research has shown that trust varies by religious tradition and frequency of church attendance, we control for both. For religious tradition, we use the RELTRAD classification scheme Steensland et al. (2000) developed by researching the history and theological perspectives of individual denominations. Respondents are placed in one of seven categories based on their reported affiliation-Catholic, black Protestant, Evangelical Protestant, Mainline Protestant, Jewish, other, and none. Those whom we classify as "other" and "none" (no religious affiliation) are not included in the analysis. Respondents who indicated that they are nondenominational Christians but go to church at least monthly were coded as Evangelicals. In our analysis, Mainline Protestantism serves as the contrast category. Church attendance ranges from 1 ("never") to 9 ("several times a week").

Image of God. Using a series of items on the BRS, we created two distinct measures of God's perceived characteristics-God's loving nature and God's level of anger. God's perceived forgiving/loving characteristics are first measured using an additive scale of four items - using how well the following adjectives describe God: "not at all," "not very well," "undecided," "somewhat well," or "very well." These adjectives are "forgiving," "friendly," "kind," and "loving." The resulting scale 
has an alpha of .91 but has a bimodal distribution. Sixty-four percent of respondents who answered the questions believe that all four adjectives describe God very well. We therefore create a dummy variable (God is all loving) where 1 = "all four adjectives describe God very well," and 0 otherwise.

God's perceived level of anger and judgment was measured by summing six items. Respondents are asked if they agree that God is "angered by human sins" and "angered by my sins." They are also asked how well the adjectives "critical," "punishing," "severe," and "wrathful" describe God. The final scale has an alpha of $.85 .^{5}$ Because this is an index without metric and is skewed, we take a natural logarithmic transformation and interpret the coefficients as elasticities.

We control for several demographic factors in our analysis: gender ( $1=$ "female" $)$, marital status ( 1 = "single never married"; 1 = "married/cohabitating"; 1 = "widowed "; 1 = "divorced") and the contrast category employment status ( 1 = "not currently employed"), and race $(1=$ "White "). Marital status is controlled using a series of dummy variables: married / cohabitating $=(0,1)$, widowed $=(0,1)$, single / never married $=(0,1)$, and divorced $=(0,1)$. Divorced is the contrast category. We also control for age (years), education (highest grade completed: eighth or less, 9 th through 12th no diploma, high school graduate, some college, trade/technical/ vocational training, college graduate, and postgraduate work/degree), income ( $\$ 10,000$ or less, $\$ 10,001$ to $\$ 20,000, \$ 20,001$ to $\$ 35,000, \$ 35,001$ to $\$ 50,000, \$ 50,001$ to $\$ 100,000, \$ 100,001$ to $\$ 150,000$, and $\$ 150,000$ or more), and region of the country (West, East, Midwest, and South), with South as the contrast category. Finally, because previous research indicates that volunteering has a positive effect on trust (Brehm and Rahn 1997; Stolle 2001), we control for the number of hours a person volunteers for the community both through and outside of their church. ${ }^{6}$ Table 1 presents descriptive statistics for independent variables.

\section{RESULTS}

Table 2 presents the weighted frequencies of our four trust measures for the full BRS sample and our subsample of the highly religious. These results show that people are generally trusting. Over 75 percent report some, or a lot of, trust in people in general. Over 80 percent report some or a lot of trust in neighbors and coworkers. Less than 10 percent report a lot of trust in those who do not believe in God. These data also show that, in general, the population is more trusting of neighbors and coworkers than they are of people in general. The highly religious are slightly more trusting of people in general, neighbors, and coworkers when compared to the full sample. The highly religious are slightly less trusting of atheists.

General Trust. Table 3 presents ordinal logit models predicting our four measures of trust among the highly religious. When it comes to general trust, the results show that Catholics and Evangelical Protestants are significantly less trusting than Mainline Protestants. Past research shows that this is not a unique finding for Evangelical Protestants (see Uslaner 2002; Welch et al. 2004). Jews are the most trusting in general. Church attendance has a net positive effect on general trust. For each unit increase in church attendance, the odds of trusting people in general increase by 7 percent. 
TABLE 1

Descriptive Statistics for Independent Variables $(N=788)$

\begin{tabular}{lcccc}
\hline & $M$ & $S D$ & Min. & Max. \\
\hline White & 0.8531 & 0.35602 & 0 & 1 \\
Age & 48.441 & 15.8178 & 18 & 91 \\
Female & 0.58234 & 0.49598 & 0 & 1 \\
East & 0.19926 & 0.40172 & 0 & 1 \\
Midwest & 0.28871 & 0.45574 & 0 & 1 \\
West & 0.17086 & 0.37853 & 0 & 1 \\
Married & 0.6376 & 0.48343 & 0 & 1 \\
Widowed & 0.06254 & 0.24351 & 0 & 1 \\
Single/never married & 0.14475 & 0.35385 & 0 & 1 \\
Divorced & 0.1551 & 0.36406 & 0 & 1 \\
Education & 4.49621 & 1.53472 & 1 & 7 \\
Income & 4.0841 & 1.57179 & 1 & 7 \\
No job & 0.34473 & 0.47798 & 0 & 1 \\
Volunteer & & & & \\
Volunteer through church & 1.54361 & 0.9746 & 1 & 5 \\
Volunteer no church & 1.81831 & 1.22194 & 1 & 5 \\
Religiosity Measures & & & & \\
Catholic & 0.24004 & 0.42954 & 0 & 1 \\
Black Protestant & 0.06822 & 0.25355 & 0 & 1 \\
Evangelical Protestant & 0.43166 & 0.49812 & 0 & 1 \\
Jewish & 0.00947 & 0.09742 & 0 & 1 \\
Mainline Protestant & 0.23225 & 0.42467 & 0 & 1 \\
Church attend & 5.7744 & 2.61257 & 1 & 9 \\
Image of God & & & & \\
Loving God & 2.87166 & 0.37786 & 1.79176 & 3.4012 \\
Angry God & 0.82056 & 0.3859 & 0 & 1 \\
\hline & & & & \\
\hline
\end{tabular}

Those who see God as all loving have greater trust in general. They are 2.04 times more likely to report trust in others than are those who do not see God as all loving. The measure for angry God shows that those who view God as being angry report less general trust. For each percentage increase on the "angry god" index, the odds of trusting people in general decline by 48 percent. Among the highly religious, the religious imagination is one of the most important determinants of trust. Among the control variables, white and older respondents have a higher likelihood of general trust. Whites are 1.87 times more likely to report trust in general than are nonwhites.

Trust and Neighbors. The data for trust of neighbors show that both loving God and angry God have anticipated effects. Those who view God as angry are less likely to trust their neighbors, while those who view God as all loving are more likely to trust their neighbors. For each percentage increase in the "angry god" index, the odds of trusting one's neighbors decline by 48 percent. However, those who see God as all loving are 1.93 times more likely to report trusting their neighbors. 
TABLE 2

Weighted Percentages for Trust Measures: Total BRS and Subsample of Highly Religious

How much would you say that you trust people in general?

\begin{tabular}{|c|c|c|}
\hline & Total Sample & Highly Religious \\
\hline Not at all & 2.72 & 2.07 \\
\hline Only a little & 14.61 & 13.5 \\
\hline Some & 65.12 & 63 \\
\hline A lot & 17.55 & 22 \\
\hline \multicolumn{3}{|c|}{ How much would you say that you trust your neighbors? } \\
\hline & Total Sample & Highly Religious \\
\hline Not at all & 2.71 & 1.67 \\
\hline Only a little & 7.88 & 6.29 \\
\hline Some & 49.61 & 47.2 \\
\hline A lot & 39.8 & 44.8 \\
\hline \multicolumn{3}{|c|}{ How much would you say that you trust your coworkers? } \\
\hline & Total Sample & Highly Religious \\
\hline Not at all & 2.58 & 2.12 \\
\hline Only a little & 10.19 & 8.58 \\
\hline Some & 50.68 & 47.7 \\
\hline A lot & 36.54 & 41.6 \\
\hline \multicolumn{3}{|c|}{$\begin{array}{c}\text { How much would you say that you trust people who do not } \\
\text { believe in God? }\end{array}$} \\
\hline & Total Sample & Highly Religious \\
\hline Not at all & 10.57 & 11 \\
\hline Only a little & 24.53 & 29 \\
\hline Some & 55.96 & 53.7 \\
\hline A lot & 8.94 & 5.7 \\
\hline
\end{tabular}

Note: BRS = Baylor Religion Survey

Among religious traditions, Catholics, Evangelical Protestants, and black Protestants are less trusting of their neighbors than are Mainline Protestants. The sharpest difference is among Mainline Protestants and black Protestants. The former are 2.5 times more likely to trust their neighbors than are black Protestants. Income and age have significant effects. Both make respondents more trusting of their neighbors.

Trust in Coworkers. The results for trust in coworkers show that both loving God and angry God have anticipated effects. Those with an image of God as all loving are 1.8 times more likely to trust their coworkers. In contrast, those with a view of God as angry are not likely to trust their coworkers. For each percentage increase in the "angry god" index, the odds of trusting one's coworker decline by 39 percent. Whereas Catholics, Evangelical Protestants, and black Protestants are 
TABLE 3

Ordinal Logit Models of Image of God and Trust among the Highly Religious

\begin{tabular}{|c|c|c|c|c|c|c|c|c|}
\hline & \multicolumn{2}{|c|}{ General Trust } & \multicolumn{2}{|c|}{ Neighbor Trust } & \multicolumn{2}{|c|}{ Coworker Trust } & \multicolumn{2}{|c|}{ Atheist Trust } \\
\hline & $b$ & $O R$ & $b$ & $O R$ & $b$ & $O R$ & $b$ & OR \\
\hline \multicolumn{9}{|l|}{ Demographics } \\
\hline White & $0.631^{*}$ & 1.88 & 0.444 & & $1.004^{* *}$ & 2.73 & 0.093 & \\
\hline Age & $0.023^{* * *}$ & 1.02 & $0.029^{* * *}$ & 1.03 & $0.018^{* *}$ & 1.02 & -0.006 & \\
\hline Female & 0.024 & & 0.047 & & 0.176 & & $0.309^{*}$ & 1.36 \\
\hline East & 0.269 & & -0.075 & & $-0.547^{*}$ & 0.58 & 0.003 & \\
\hline Midwest & 0.135 & & 0.182 & & 0.146 & & 0.249 & \\
\hline West & -0.377 & & -0.263 & & -0.157 & & 0.149 & \\
\hline Married & -0.291 & & 0.261 & & 0.027 & & -0.391 & \\
\hline Widowed & -0.161 & & 0.184 & & -0.161 & & 0.006 & \\
\hline $\begin{array}{l}\text { Single/never } \\
\text { married }\end{array}$ & -0.478 & & 0.459 & & 0.164 & & -0.338 & \\
\hline Education & 0.091 & & -0.035 & & 0.11 & & 0.085 & \\
\hline Income & 0.076 & & $0.228^{* * *}$ & 1.26 & $0.137^{*}$ & 1.15 & $0.161^{* *}$ & 1.17 \\
\hline No job & 0.066 & & -0.381 & & $-1.06^{* * *}$ & 0.35 & 0.051 & \\
\hline \multicolumn{9}{|l|}{ Volunteer } \\
\hline $\begin{array}{l}\text { Volunteer } \\
\text { through } \\
\text { church }\end{array}$ & -0.068 & & 0.106 & & -0.027 & & -0.101 & \\
\hline $\begin{array}{l}\text { Volunteer no } \\
\text { church }\end{array}$ & $0.166^{*}$ & 1.18 & 0.025 & & 0.053 & & 0.1091 & \\
\hline \multicolumn{9}{|l|}{$\begin{array}{l}\text { Religiosity } \\
\text { measures }\end{array}$} \\
\hline Catholic & $-0.473^{*}$ & 0.62 & $-0.778^{* * *}$ & 0.46 & 0.105 & & -0.271 & \\
\hline $\begin{array}{l}\text { Black } \\
\text { Protestant }\end{array}$ & -0.403 & & $-0.923^{*}$ & 0.40 & -0.241 & & $-1.14^{* * *}$ & 0.32 \\
\hline $\begin{array}{l}\text { Evangelical } \\
\text { Protestant }\end{array}$ & $-0.622^{* * *}$ & 0.54 & $-0.781^{* * *}$ & 0.46 & $-0.407^{* * *}$ & 0.67 & -0.264 & \\
\hline Jewish & 1.61 & & 0.742 & & 0.128 & & 1.05 & \\
\hline Church attend & 0.076 & 1.08 & 0.024 & & $0.0902^{* * *}$ & 1.09 & 0.015 & \\
\hline \multicolumn{9}{|l|}{ Image of God } \\
\hline Loving God & $0.571^{* *}$ & 1.77 & $0.661^{* * *}$ & 1.94 & $0.589^{* *}$ & 1.80 & $0.431^{*}$ & 1.54 \\
\hline Angry & -0.508 & 0.60 & $-0.655^{* * *}$ & -0.66 & $-0.497^{*}$ & 0.61 & $-0.586^{* *}$ & 0.56 \\
\hline Intercept 4 & $-3.02^{* *}$ & & 1.663 & & $-2.58^{* *}$ & & $-2.57^{* *}$ & \\
\hline Intercept 3 & 0.506 & & 1.193 & & 0.251 & & 0.898 & \\
\hline Intercept 2 & $2.66^{* * *}$ & & $2.875^{* * *}$ & & $2.646^{* * *}$ & & $2.57^{* *}$ & \\
\hline R-square & $0.137^{* * *}$ & & $0.162^{* * *}$ & & $0.191^{* * *}$ & & $0.083^{* * *}$ & \\
\hline $\begin{array}{l}\text { Model } \\
\text { chi-square }\end{array}$ & $115.3^{* * *}$ & & $139.2^{* * *}$ & & $144.3^{* * *}$ & & $67.9^{* * *}$ & \\
\hline$N$ & 781 & & 783 & & 681 & & 776 & \\
\hline
\end{tabular}

Note: OR $=$ Odds Ratio

${ }^{*} p<.05 ;{ }^{* *} p<.01 ;{ }^{* * *} p<.001$. 
all less trusting of their neighbors than are Mainline Protestants, when it comes to coworkers, the only difference is between Mainline Protestants and Evangelical Protestants. The former are 1.5 times more likely to report trusting their coworkers. Among the control variables, income and age have positive effects on trust in coworkers. Not surprisingly, those without a job are much less likely to trust former coworkers. White respondents are 2.73 times more likely to trust their coworkers than are nonwhites.

Trust in Atheists. The last question deals with religious affiliation. Previous research suggests that the bonding ties of congregational life can make one less trusting of outsiders. Among Christians, this may apply to people of other Christian denominations (Uslaner 2002; Welch et al. 2004). In this last model, we test trust in those who do not believe in God, perhaps the ultimate outsiders for the highly religious. Black Protestants have significantly lower levels of trust of those who do not believe in God than do Mainline Protestants. Black Protestants are 3.2 times less likely to trust atheists than are Mainline Protestants. Also, the coefficients for Catholics and Evangelical Protestants are negative. However, they are not significant at the .05 level.

Having a perception of God as angry makes one less trusting of those who do not believe in God. These findings are not surprising. We expect those from more conservative Christian backgrounds to be more suspicious of those who have no faith (Uslaner 2001). An all loving image of God, however, makes one more trusting of atheists. They are 54 percent more likely to trust atheists than are those who do not report an all loving image of God. Net of these religiosity measures, highly religious females are 36 percent more likely to trust atheists than are highly religious males. Income has a net, positive effect on trust in atheists. ${ }^{7}$

\section{CONCLUSION}

We cannot enter into mutually beneficial reciprocal relations with others without some modicum of trust. Many facets of a social life that leads to more or less trust have been examined (e.g., Fukuyama 1995; Knight 2001; Putnam 1995; Veenstra 2002). It is clear that religion exerts a powerful effect on trust. What we believe to be a key measure of religiosity-images of God-has been virtually ignored in research on trust. As Greeley (1988, 1989, 1991, 1993, 1995) argues, knowing how an individual conceives of God provides deep insight into how religion affects that person's world view:

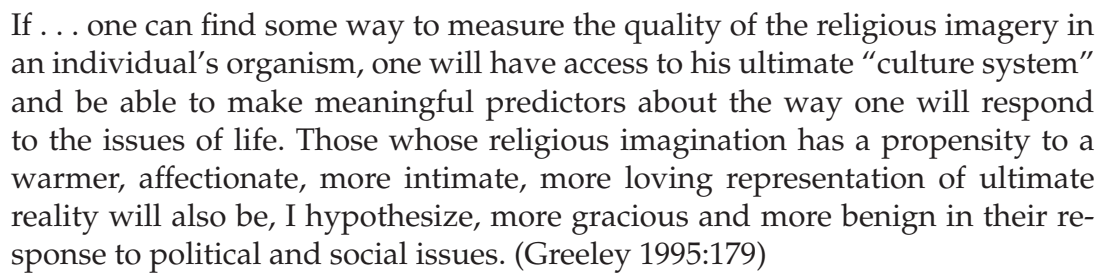

The characteristics we assign to God, and to how God judges human behavior, reveal something about ourselves. It transfers to God our view of human nature. 
Greeley expects that the manner in which we anthropomorphize God affects how we view our fellow citizens. A person who believes that God is judgmental should be more judgmental of others. Someone who believes God to be endlessly forgiving should show similar mercy to others.

Images of God, therefore, provide us a measure of religion that is uniquely religious in nature. It is possible that the effects of church attendance or even religious tradition-important determinants of trust in previous research (see Welch et al. 2004) - simply reflect the sharing of values. Any type of societal institution that promotes shared beliefs, whether religious in nature or not, could theoretically have similar effects. How religion differs from other societal institutions is in its focus on a relationship with an unseen, supernatural authority of authorities (Smith 2003). Images of God provide us with a window into the uniquely religious aspects of a person's world view. The question is, Does someone's view of "ultimate authority" affect levels of trust?

Indeed, we find that among the highly religious, those with a more loving view of God are more trusting, and those with a view of God as being more angry/ judgmental are significantly less trusting. Belief in a loving, forgiving God can build bonds of trust, while beliefs in a judgmental, wrathful God tend to make believers more wary of others. Particularized and generalized versions of trust are the products of different religious imaginations and religious narratives. Smith (2003:86) maintains that narratives compete with one another. For example, he argues that in sociology two of the dominant narratives that organize the discipline are the Liberal Progress (the foundation of the conflict/inequality orientation) and Ubiquitous Egoism (which supports a rational choice/naturalistic approach) narratives. One's entire approach to sociological questions (deductive vs. inductive, qualitative vs. quantitative, core assumptions, etc.) is organized by the sociological narrative in which the researcher is trained and socialized.

We propose the same argument when it comes to understanding bridging and bonding ties and social trust. When some religious groups build bridging ties, it is likely that these groups have at their core a religious narrative that emphasizes greater moral flexibility and a symbol of God as a loving, forgiving entity. Conversely, those groups that build social bonding ties have narratives grounded in a religious imagination with greater moral absolutism. The individual is responsible to struggle and rise above the cesspool of human sin.

Our data also show that trust cannot simply be reduced to Catholic versus Protestant world views, which we believe Greeley (1995) leans toward in his arguments. While Catholics may embrace an analogical world view, they are no more trusting than Mainline Protestants. However, Catholics and Mainline Protestants have greater moral flexibility in their religious narratives (Steensland et al. 2000; Welch et al. 2004) than do Evangelical Protestants. A subsequent analysis of variance (ANOVA) confirms this. Evangelical Protestants have average "angry god" index scores 13.7 percent higher than Mainline Protestants and 17.5 percent higher than Catholics, while there is no statistical difference between Mainline Protestants and Catholics. When Greeley (1995) discusses differences between Catholics and Protestants, these differences to which he speaks are primarily between Catholics and Evangelical Protestants. In fact, our regression analysis shows that 
Mainline Protestants have higher levels of general trust and coworker trust than do Catholics.

There are several important ways in which our findings can inform the general literature on social trust. Our analysis of highly religious persons indicates that many of the previous effects of religious denomination (see Smidt 1999; Stark and Finke 2000; Uslaner 2001, 2002; Welch et al. 2004; Welch et al. 2005; Wuthnow 1998) might be spurious. In our analysis, we find that image of God has consistent effects across all four trust models. Religious tradition guarded effects. Mainline Protestants are more trusting in general and of coworkers. The coefficients in the other two models are in the expected direction but do not reach the .05 level of significance.

It is not the tradition that affects trust but the religious story taught and brought forth from the narratives and how they are manifested in the symbolic image of God in the religious story of the individual. This is not to say that religious tradition does not matter, but it may be more important for other dimensions of social capital, such as volunteering (see Smidt 1999). This is an important finding for the general trust literature. Because the United States is a religious nation (see above), religious measures, such as image of God, will be important determinants of trust for a significant subset of the American population. Future research on what factors determine level of trust needs to take this into account.

Second, Veenstra (2002:551) points out that there are different dimensions of trust in social life. Trusting one's family and friends is different than trusting coworkers, neighbors, people in general, and social institutions. What we have to contribute to this literature is that among the highly religious, image of God is a constant determinant of many different types of trust. Those with a loving image of God are more trusting of neighbors, colleagues, and even atheists. Those with an image of God as wrathful are less trusting. Moreover, Veenstra (2002) challenges Gidden's assumption that older systems of trust generation (including religion) are being replaced with newer systems of trust generation. Our data find that among the two-thirds of Americans we classify as highly religious, their religious narrative is a very important and consistent determinant of trust. Our data suggest that Veenstra's challenge is well grounded.

The implications of our research for the rational choice approach to trust formation advocated by Yamagishi et al. (1998) is less clear. Their research focuses on experiments with prisoner dilemma models. Trust is seen as a form of risk reduction in exchange. What our data indicate is that people, particularly religious people in the United States, may enter into exchanges with preconceived notions about trust based on their religious narrative. To what extent this would lead to different outcomes in their experiments, at least with Americans, is unclear.

The final area on which we comment concerns the causality between trust and volunteering. A significant body of literature indicates that the more individuals volunteer in their communities, the higher the level of trust they will have (see Brehm and Rahn 1997; Putnam 2000; Stolle 2001). Others have maintained that trust precedes social involvement (Tonkiss and Passey 1999). Still others maintain that the relationships between volunteering and trust are inconsistent (Clairbourn and Martin 2000; Smidt 1999). Our data show that volunteering has no consistent 
effect on trust among the highly religious, once image of God is included in the model. We believe that the next logical step is to move beyond the effect of images of God on beliefs and attitudes and examine the relationship between image of God and actions.

Clearly religious beliefs can inspire us to action (Woodberry and Smith 1998). The character of God has been the catalyst for social movements (abolitionist and civil rights) and also wars (Froese and Bader 2008). It is at the heart of the culture wars. As we have shown here, the character of God will also affect how we trust others. This, in turn, will have an effect on the accumulation of social capital, the reciprocal networks of good will upon which community and social organization are based. Those wishing to increase local stocks of social capital to increase prosocial behavior (Lee and Bartkowski 2004) or foster locally driven economic development (see Lyson 2006; Lyson and Tolbert 2004) will be well advised to understand the important role the image of God can play in this process of accumulation. We propose that future studies of trust recognize the important role religion, in general, and image of God, in particular, play in determining trust for a significant portion of Americans.

Acknowledgments: We would like to thank Dr. Paul Froese and anonymous reviewers for their helpful comments. We also thank the John Templeton Foundation for their financial support of the Baylor Religion Survey.

\section{NOTES}

1. Symbols can be subdivided into two groups: primary and activating. Primary symbols are those at the core of our existential understanding. Activating symbols are those that recall the primary symbol from our subconscious. Greeley provides the example of a glance at a mother and child during a harried pass through Chicago's O'Hare Airport. The smiling mother and child was an activating symbol that brought from the subconscious the image of Mary and Jesus, a primary symbol of God's love in the Christian faith.

2. Other studies have focused on gender and age differences in people's images of God (Nelsen, Cheek, and Au 1985; Noffke and McFadden 2001), parents' influences on their children's images of God (Dickie et al. 1997; Dickie et al. 2006), religious activities and images of God (Benson and Spilka 1973), and religious commitment (Hammersla, Andrews-Qualls, and Frease 1986).

3. The data are weighted. For full information on the sampling methodology and weighting of the BRS, see Bader et al. 2007.

4. We want to caution readers from drawing the conclusion that the BRS is biased toward highly religious respondents. We note that the 2005 BRS compares very favorably to the 2004 General Social Survey on many important religiosity measures, including church attendance, believing in God, and religious affiliation (see Bader et al. 2007 for more details).

5. Conceptually, we do not preclude the possibility that one might view God as both loving and angry.

6. We work from the conclusions of Brehm and Rahn (1997) that civic participation has a greater effect on trust than trust has on civic participation. Moreover, the two measures of volunteering are positively correlated at 242 . 
7. We examined interaction effects between image of God and religious tradition. We did not find that angry God has a different effect on trust for any of the religious traditions. The same conclusion applies to loving God.

\section{REFERENCES}

Bader, Christopher, F. Carson Mencken, and Paul Froese. 2007. “American Piety 2005: Content, Methods, and Selected Results from the Baylor Religion Survey." Journal for the Scientific Study of Religion 46:447-63.

Baker, Wayne. 2005. America's Crises of Values: Reality and Perception. Princeton, NJ: Princeton University Press.

$\rightarrow$ Benson, Peter and Bernard Spilka. 1973. “God Images as a Function of Self Esteem and Locus of Control." Journal for the Scientific Study of Religion 12:297-310.

$\rightarrow$ Brehm, John and Wendy Rahn. 1997. "Individual Level Evidence for the Causes and Consequences of Social Capital." American Journal of Political Science 41:999-1023.

Clairbourn, Michele P. and Paul S. Martin. 2000. "Trusting and Joining? An Empirical Test of the Reciprocal Nature of Social Capital." Political Behavior 22:267-91.

Coleman, James S. 1988. "Social Capital in the Creation of Human Capital." American Journal of Sociology 94(Supplement):s120.

- 1990. Foundations of Social Theory. Cambridge, MA: The Belknap Press of Harvard University Press.

$\rightarrow$ Dickie, Jane R., Lindsey V. Ajega, Joy R. Kobylak, and Kathryn M. Nixon. 2006. "Mother, Father, and Self: Sources of Young Adults' God Concepts." Journal for the Scientific Study of Religion 45:57-71.

$\rightarrow$ Dickie, Jane R., Amy K. Eshleman, Dawn M. Merasco, Amy Shepard, Michael Vander Wilt, and Melissa Johnson. 1997. "Parent-Child Relationships and Children's Images of God." Journal for the Scientific Study of Religion 36:25-43.

Ellison, Christopher. 1991. "An Eye for an Eye? A Note on the Southern Subculture of Violence Thesis." Social Forces 69:1223-39.

Froese, Paul and Christopher Bader. 2007. "God in America: Why Theology Is not Simply the Concern of Philosophers." Journal for the Scientific Study of Religion 46:465-81.

Froese, Paul and Christopher Bader. 2008. "Unraveling Religious Worldviews: The Relationship between Images of God and Political Ideology in a Cross-Cultural Analysis." The Sociological Quarterly 49(4):689-718.

Froese, Paul, Christopher D. Bader, and Buster Smith. 2008. "When Faith and Freedom Collide: Religion and Political Tolerance in the United States." Sociology of Religion 69(1).

Fukuyama, Francis. 1995. Trust: The Social Virtues and the Creation of Prosperity. New York: Free Press.

Greeley, Andrew M. 1988. "Evidence that a Maternal Image of God Correlates with Liberal Politics." Sociology and Social Research 72:150-54.

- 1989. Religious Change in America. Cambridge, MA: Harvard University Press.

—. 1991. "Religion and Attitudes towards AIDS Policy." Sociology and Social Research 75:126-32.

$\rightarrow$ - 1993. "Religion and Attitudes toward the Environment." Journal for the Scientific Study of Religion 32:19-28.

. 1995. Religion as Poetry. New Brunswick, NJ: Transaction Publishers.

$\rightarrow$ Hammersla, Joy Fisher, Lisa C. Andrews-Qualls, and Lynne G. Frease. 1986. “God Concepts and Religious Commitment among Christian University Students." Journal for the Scientific Study of Religion 25:424-35. 
Knight, Jack. 2001. "Social Norms and the Rule of Law: Fostering Trust in a Socially Diverse Society." Pp. 354-73 in Trust in Society, Vol. II, The Russell Sage Foundation Series on Trust, edited by K. S. Cook. New York: Russell Sage Foundation.

$\rightarrow$ Lee, Matthew and John P. Bartkowski. 2004. "Love Thy Neighbor? Moral Communities, Civic Engagement, and Juvenile Homicide in Non-Metro Counties." Social Forces 82:1001-35.

Lyson, Thomas. 2006. Civic Agriculture: Reconnecting Farm, Food, and Community. Lebanon, NH: Tufts University Press.

—. and Charles M. Tolbert. 2004. "Civil Society, Civic Communities, and Rural Development." Pp. 228-40 in Challenges for Rural America in the Twenty-First Century, edited by D. L. Brown and L. E. Swanson. University Park: The Pennsylvania State University Press.

Macy, Michael W. and John Skvoretz. 1998. "The Evolution of Trust and Cooperation between Strangers: A Computational Model." American Sociological Review 63:648-60.

Nelsen, Hart M., Neil H. Cheek, and Paul Au. 1985. "Gender Differences of God." Journal for the Scientific Study of Religion 24:396-402.

Noffke, Jacqueline L. and Susan H. McFadden. 2001. "Denominational and Age Comparisons of God Concepts." Journal for the Scientific Study of Religion 40:747-56.

Norris, Pippa and Ronald Inglehart. 2004. Sacred and Secular: Religion and Politics Worldwide. Cambridge, UK: Cambridge University Press.

$\rightarrow$ Ozorak, Elizabeth. 2003. "Love of God and Neighbor: Religion and Volunteer Service among College Students." Review of Religious Research 44:285-99.

$\rightarrow$ Paxton, Pamela. 2000. "Social Capital and Democracy: An Interdependent Relationship." American Sociological Review 67:254-77.

$\rightarrow$ Putnam, Robert D. 1995. "Bowling Alone: America's Declining Social Capital." Journal of Democracy 6:65-78.

. 2000. Bowling Alone. New York: Simon \& Schuster.

Saguaro Seminar. 2000. "Better Together: Report of the Saguaro Seminar on Civic Engagement in America." John F. Kennedy School of Government, Cambridge, MA. Available at bettertogether.org

$\rightarrow$ Smidt, Corwin. 1999. "Religion and Civic Engagement: A Comparative Analysis." The Annals of the American Academy of Political and Social Science 565(1): 176-92.

Smith, Christian. 2003. Moral, Believing Animals: Human Personhood and Culture. New York: Oxford University Press.

$\rightarrow$ Somers, Margaret R. 1992. "Narrativity, Narrative Identity, and Social Action: Rethinking English Working-Class Formation." Social Science History 16:591-630.

Stark, Rodney. 2001a. One True God: The Historical Consequences of Monotheism. Princeton, NJ: Princeton University Press.

$\rightarrow$ - 2001b. "Gods, Rituals, and the Moral Order." Journal for the Scientific Study of Religion 40:619-36.

- and Roger Finke. 2000. Acts of Faith. Berkeley: University of California Press.

$\rightarrow$ Steensland, Brian, Jerry Z. Park, Mark D. Regnerus, Lynn D. Robinson, W. Bradford Wilcox, and Robert D. Woodberry. 2000. "The Measure of American Religion: Toward Improving the State of the Art." Social Forces 79:291-318.

Stolle, Dietlind. 2001. "Clubs and Congregations: The Benefits of Joining an Association." Pp. 202-44 in Trust in Society, Vol. II, The Russell Sage Foundation Series on Trust, edited by K. S. Cook. New York: Russell Sage Foundation.

Tonkiss, Fran and Andrew Passey. 1999. "Trust, Confidence, and Voluntary Organizations: Between Values and Institutions." Sociology 33:257-74. 
$\rightarrow$ Unnever, James D., Frances T. Cullen, and John P. Bartkowski. 2006. “Images of God and Public Support for Capital Punishment: Does a Close Relationship with a Loving God Matter?" Criminology 44:835-66.

Unnever, James D., Frances T. Cullen, and Brandon Applegate. 2005. "Turning the Other Cheek: Reassessing the Impact of Religion on Punitive Ideology." Justice Quarterly 22:304-38.

Uslaner, Eric M. 2001. "Volunteering and Social Capital: How Trust and Religion Shape Civic Participation in the United States." Pp. 104-17 in Social Capital and Participation in Everyday Life, edited by P. Dekker and E. Uslaner. London: Routledge.

$\rightarrow$ - 2002. "Religion and Civic Engagement in Canada and the United States." Journal for the Scientific Study of Religion 41:239-54.

$\rightarrow$ Veenstra, Geery. 2002. "Explicating Social Capital: Trust and Participation in the Civil Space." Canadian Journal of Sociology 27:547-72.

$\rightarrow$ Yamagishi, Toshio, Karen S. Cook, and Motoki Watabe. 1998. “Uncertainty, Trust, and Commitment Formation in the United States and Japan." The American Journal of Sociology 104:165-94.

$\rightarrow$ Welch, Michael R., Roberto E. N. Rivera, Brain P. Conway, Jennifer Yonkoski, Paul M. Lupton, and Russell Giancola. 2005. "Determinants and Consequences of Social Trust." Sociological Inquiry 75:453-73.

$\rightarrow$ Welch, Michael R., David Sikkink, Eric Sartain, and Carolyn Bond. 2004. "Trust in God and Trust in Man: The Ambivalent Role of Religion in Shaping Dimensions of Social Trust." Journal for the Scientific Study of Religion 43:317-43.

$\rightarrow$ Woodberry, Robert and Christian Smith. 1998. "Fundamentalism et al.: Conservative Protestants in America." Annual Review of Sociology 24:25-46.

Wuthnow, Robert. 1991. Acts of Compassion: Caring for Others and Helping Ourselves. Princeton, NJ: Princeton University Press. . 1998. Loose Connections: Joining Together in America's Fragmented Communities. Cambridge, MA: Harvard University Press. 